\title{
Development and evaluation of a booklet to promote healthy lifestyle in people with HIV
}

\author{
Desenvolvimento e avaliação de cartilha para promover estilo de vida saudável em pessoas com HIV \\ Desarrollo y evaluación de cartilla para promover estilo de vida saludable en personas con VIH
}

\author{
Marina Soares Monteiro Fontenele' \\ ORCID: 0000-0002-8781-5645 \\ Gilmara Holanda da Cunha' \\ ORCID: 0000-0002-5425-1599 \\ Marcos Venícios de Oliveira Lopes' \\ ORCID: 0000-0001-5867-8023 \\ Larissa Rodrigues Siqueira' \\ ORCID: 0000-0001-6948-9834 \\ Maria Amanda Correia Lima' \\ ORCID: 0000-0001-6244-3964 \\ Lavna Albuquerque Moreira' \\ ORCID: 0000-0002-4787-4747
}

'Universidade Federal do Ceará. Fortaleza, Ceará, Brazil.

How to cite this article: Fontenele MSM, Cunha GH, Lopes MVO, Siqueira LR, Lima MAC, Moreira LA. Development and evaluation of a booklet to promote healthy lifestyle in people with HIV. Rev Bras Enferm. 2021;74(Suppl 5):e20200113. doi: http://dx.doi.org/10.1590/0034-7167-2020-0113

Corresponding author:

Gilmara Holanda da Cunha

E-mail: gilmaraholandaufc@yahoo.com.br

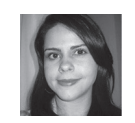

EDITOR IN CHIEF: Antonio José de Almeida Filho ASSOCIATE EDITOR: Alexandre Balsanelli

Submission: 02-20-2020 Approval: 09-21-2020

\begin{abstract}
Objective: To develop and evaluate an educational primer to promote healthy lifestyles in people with HIV. Methods: Study of technological development in three stages: Development of the booklet, with bibliographical review, illustrations, layout, diagramming, adopting as reference the trans-theoretical model of behavior change; Analysis of content and appearance by 22 judges; Semantic analysis by 22 people with HIV. The proportion of positive evaluations of the items was measured, considering a percentage equal to or greater than $85 \%$. Results: My motivational booklet for change! Practices for promoting a healthy lifestyle" had six areas: Body weight control; Healthy eating; Exercise practice; Smoking, alcohol and other drugs; Stress control; and Drug treatment. Most of the items evaluated agreed with an overall average of $92.4 \%$ by the judges and $98.9 \%$ by the target audience. Conclusion: The booklet had evidence of adequate validity to be used by people with HIV.
\end{abstract}

Descriptors: Educational Technology; HIV; Chronic Disease; Health Promotion; Nursing.

\section{RESUMO}

Objetivo: Desenvolver e avaliar uma cartilha educativa para promover estilo de vida saudável em pessoas com HIV. Métodos: Estudo de desenvolvimento tecnológico em três etapas: Desenvolvimento da cartilha, com revisão bibliográfica, ilustrações, layout, diagramação, adotandose como referencial o modelo transteórico de mudança de comportamento; Análise de conteúdo e aparência por 22 juízes; Análise semântica por 22 pessoas com HIV. Foi mensurada a proporção de avaliações positiva dos itens, considerando-se percentual igual ou maior a 85\%. Resultados: A "Minha cartilha de motivação para mudança! Práticas para promoção do estilo de vida saudável" teve seis domínios: Controle do peso corporal; Alimentação saudável; Prática de exercício físico; Fumo, álcool e outras drogas; Controle do estresse; e Tratamento medicamentoso. A maioria dos itens avaliados obteve percentual de concordância com média global de $92,4 \%$ pelos juízes e de $98,9 \%$ pelo público-alvo. Conclusão: A cartilha teve evidência de validade adequada para ser utilizada pelas pessoas com HIV. Descritores: Tecnologia Educacional; HIV; Doença Crônica; Promoção da Saúde; Enfermagem.

\section{RESUMEN}

Objetivo: Desarrollar y evaluar cartilla educativa para promover estilo de vida saludable en personas con VIH. Métodos: Estudio de desarrollo tecnológico en tres etapas: Desarrollo de la cartilla, con revisión bibliográfica, ilustraciones, plan, diagramación, basado en el modelo trasteórico de cambio; Análisis de contenido y apariencia por 22 jueces; Análisis semántico por 22 personas con VIH. Mensurada la proporción de evaluaciones positivas de los ítems, considerándose porcentual igual o mayor a 85\%. Resultados: "Mí cartilla de motivación para cambio! Prácticas para promoción del estilo de vida saludable" tuvo seis dominios: Control del peso; Alimentación saludable; Prácticas de ejercicios; Tabaco, alcohol y otras drogas; Control del estrés; y Tratamiento medicamentoso. La mayoría de los ítems evaluados obtuvo porcentual de concordancia con medina global de $92,4 \%$ por los jueces y de $98,9 \%$ por el público objeto. Conclusión: La cartilla tuvo evidencia de validez adecuada para ser utilizada por las personas con VIH.

Descriptores: Tecnología Educacional; VIH; Enfermedad Crónica; Promoción de la Salud; Enfermería. 


\section{INTRODUCTION}

Early diagnosis of positive HIV serology and antiretroviral therapy (ART) have reduced the morbidity and mortality of people living with HIV (PLWHA) $)^{(1-2)}$. However, an increased frequency of chronic non-communicable diseases (CNCDs) has been observed in this population, such as diabetes mellitus (DM), cardiovascular and pulmonary diseases, and neoplasms, so research has sought to identify the factors influencing the occurrence of these comorbidities ${ }^{(3-6)}$.

A study conducted in Brazil evaluated the nutritional and metabolic profile of PLWHA in specialized outpatient services, showing a high prevalence of dyslipidemias (68.5\%), overweight (41.8\%), systemic arterial hypertension (SAH) (25.5\%), DM (11.5\%) and sedentary lifestyle (61.2\%), pointing out risk factors and CNCDs in these individuals ${ }^{(7)}$. Furthermore, PLWHA are at increased risk for cardiovascular disease compared to the general population, which was demonstrated in research conducted in the United States, where people with HIV were 4.7 times more likely to have $\mathrm{SAH}$ compared to those without $\mathrm{HIV}^{(8)}$. Other studies have found that most HIV patients had unhealthy lifestyles, did not exercise regularly, had high consumption of fatty foods, smoking, and use of alcoholic beverages, which are risk factors for CNCDs, such as $\mathrm{SAH}$ and DM, and some already had these diseases ${ }^{(9-10)}$.

The incidence of cardiovascular disease and DM in PLWHA increases due to risk factors, ageing and long-term adverse effects of $A R T^{(11-13)}$. Persistent immune activation associated with HIV infection itself promotes inflammation and endothelial injury, contributing to increased cardiovascular risk ${ }^{(11,14)}$. As for ART, studies show that a high proportion of PLWHA treated with certain antiretroviral drugs, especially protease inhibitors, have metabolic disorders involving dyslipidemias, insulin resistance, lipodystrophy and lipoatrophy, increasing the risk of cardiovascular and endocrine diseases ${ }^{(12,15)}$.

In addition, the use of addictive substances can trigger competition and interactions with antiretroviral drugs, interfering with their binding to proteins, and can lead to an increased risk of toxicity and ineffective therapy due to changes in the concentration of the drug in plasma ${ }^{(16)}$. Harmful alcohol use also makes PLWHA more likely to stop or forget to take antiretroviral drugs, and there is damage to therapeutic adherence and efficacy ${ }^{(17)}$. Smoking promotes a reduction in adiponectin production, generating an increased risk of endothelial dysfunction and insulin resistance ${ }^{(18)}$. In addition, the stress and stigma of positive anti-HIV serology can lead individuals to adopt unhealthy lifestyles, acquiring practices such as smoking, alcohol and illicit drug use, inadequate diet and physical inactivity ${ }^{(19)}$. Thus, lifestyle is a major factor in the emergence and maintenance of CNCDs, and making it healthier is essential for the prevention and control of comorbidities, and this issue should be addressed in the follow-up of PLWHA.

Educational actions to promote a healthy lifestyle can be facilitated by printed educational materials, especially when constructed and evaluated with theoretical and methodological rigors. For the production of quality printed materials, three aspects are considered: language, layout and illustration. It is necessary to select information that stimulates reflection and motivation to achieve the proposed objectives. The material must be visually attractive, accessible and in language appropriate to the socio-economic and cultural context of the target audience ${ }^{(20)}$.
Studies have built and evaluated educational booklets for guidance on various nursing care topics, such as: tracheostomy care $^{(21)}$, promotion of sexual activity in people with spinal cord injuries ${ }^{(22)}$, prevention of childhood diarrhea ${ }^{(23)}$ and falls in the elderly ${ }^{(24)}$, among others. Despite several primers, an integrative review of the literature conducted by the author of this article found a lack of research with educational technologies to promote a healthy lifestyle in PLWHA. This occurs because the health care to these patients is still very focused on ART, but there is a need for more comprehensive guidance ${ }^{(6,12-13)}$.

Thus, it was perceived the need for the construction of a simple educational technology as the booklet, so that PLWHA without access to the Internet could clarify doubts, register the monitoring in health, reinforcing the guidelines provided in the consultations. In this context, for the construction of an educational technology, it is important to use a theoretical reference to guide its elaboration. The theoretical reference serves as a basis for clinical practice, contributing to the definition of the roles of nursing, its specificities and knowledge, as well as scientific development, being important to choose a reference that is appropriate to the characteristics of the reality and profile of clients ${ }^{(25)}$. In this study, we used the Trans-theoretical Model of Behavior Change (TTM), which represents a fundamental theoretical advance for the understanding of when, how and why people change their health-related behaviors, because it considers behavior change not an event, but a process, in which individuals have different levels of motivation for change $\mathrm{e}^{(26)}$.

In light of the above, the questions of the research were: What information should a booklet have to guide PLWHA on the healthy lifestyle for the prevention/control of CNCDs? The booklet is adequate in terms of content and appearance, as evaluated by health professionals, and is understood by the target audience?

This study may contribute to the educational actions to promote the health of PLWHA, especially for low-income patients without access to electronic technologies.

\section{OBJECTIVE}

Develop and evaluate an educational primer for the promotion of healthy lifestyle in PLWHA.

\section{METHODS}

\section{Ethical aspects}

According to Resolution $466 / 2012^{(27)}$, the project was approved by the Research Ethics Committee of the Federal University of Ceará (UFC) and by the coparticipating institution, the UFC Walter Cantídio University Hospital (HUWC).

\section{Design, time and place of study}

Study of educational technology development, carried out between March 2018 and November 2019, in Fortaleza, Ceará, in three stages: 1. Development of the educational booklet; 2. Analysis of content and appearance by the specialized judges; and 3. Semantic analysis by PLWHAs. 


\section{Population, sample, inclusion and exclusion criteria}

Expert judges and PLWHA participated in the study. The sample was calculated based on the formula for infinite population ${ }^{(28)}, \mathrm{n}=\mathrm{Za}^{2}$.P.(1-P)/d $\mathrm{d}^{2}$, adopting a minimum proportion of $85 \%$ of agreement, with the relevance of each item evaluated and a $15 \%$ difference in this agreement. The final calculation was determined by $n=(1.96) 2 .(0.85) \cdot(0.15) /(0.15)^{2}$, with a sample of 22 expert judges with expertise in HIV. This sample calculation was also used to determine the sample for semantic analysis, in which 22 PLWHA participated.

In the analysis of content and appearance by the expert judges, intentional non-probabilistic sampling was carried out, based on adapted inclusion criteria ${ }^{(29)}$, Adopting a minimum of 6 points: have a master's degree (1 point) and/or a doctorate in health ( 2 points); dissertation (1 point) and/or thesis involving health care for PLHIV (2 points); published article involving PLHIV (1 point); participate in an HIV research project (1 point); be a teacher of health courses on care for PLHIV (2 points); and have professional experience in hospitals or HIV referral clinics (2 points). In the semantic analysis for the 22 PLHIVs, the inclusion criteria were: age 18 or older; be able to read the material and understand it, having more than 35 points on the Health Literacy Scale ${ }^{(30)}$. These were recruited by convenience sampling at the HUWC Infectious Disease Outpatient Clinic.

\section{Study Protocol}

The first stage of the study was the development of the booklet. To select the content to be addressed, an integrative review of the literature was conducted, with the guiding question: "What are the health education practices directed at PLWHA to promote a healthy lifestyle and prevent other chronic health conditions? Articles were selected from five databases: Medical Literature Analysis and Retrieval System Online (MEDLINE), Cumulative Index to Nursing and Allied Health Literature (CINAHL), Índice Bibliográfico Español de Ciencias de La Salud (IBECS), Latin American and Caribbean Literature in Health Sciences (LILACS) and SCOPUS. Also, an electronic library, the Scientific Electronic Library Online (SciELO), was used. To the results obtained in the integrative review, guidelines of the current guidelines for treatment of PLWHA were added ${ }^{(18)}$ and guidelines for prevention and control of CNCDs ${ }^{(31)}$. Textual elaboration was done by the researcher, and a graphic designer did the illustration, layout and diagramming.

The theoretical reference for building the booklet was the Trans-theoretical Model of Behavior Change (TTM), which focuses on the intentional change and decision making of the individual, as opposed to change by social/biological influence of behavior, on which other approaches focus. In TTM, changes in health behavior occur in five stages: pre-contemplation, contemplation, preparation, action and maintenance ${ }^{(26)}$. A methodological reference was also adopted to structure the aspects of the booklet as to language, illustration and layout ${ }^{(21)}$.

After the construction of the booklet, the second stage of the study took place, the analysis of content and appearance by the expert judges, who were 22 professionals with expertise in the area of HIV. The search for the names of the professionals took place at the Lattes Platform of the National Council for Scientific and Technological Development (CNPq), selecting those who met the inclusion criteria ${ }^{(29)}$. They were invited by invitation letter, via e-mail or in person and, with the acceptance to participate in the study, received a kit with a Free and Informed Consent Term (FICT), a colorful educational booklet and an evaluation tool adapted from another already validated ${ }^{(32)}$, containing two parts: 1. identification and training data (name, age, gender, profession, length of training, degree, research projects, area of work, institution, function/occupation, length of time in the area, scientific production, experience in validating educational instruments/materials); and 2. Analysis of the educative booklet (objectives, structure, presentation, clarity, comprehension of texts and illustrations, motivation for reading and relevance). The answers to the questions were in dichotomous scale: (1) Yes - according to the item; (2) No - in disagreement with the item. In addition, there were spaces for suggestions. It was stipulated a period of 15 days for evaluation; in case they did not return the questionnaire and FICT, there was another 15 days for delivery, being the person excluded from the research after this period. In this study, there were no exclusions.

In the third stage, the semantic analysis by PLWHA, was verified if the texts of the booklet were comprehensible to the patients, considering individuals from different schools and socioeconomic levels. Those who met the inclusion criteria read the booklet in a private environment, responding to the adapted assessment tool ${ }^{(32)}$, with two parts: 1 . identification data (name, age, sex, number of years of study, exposure category, time of diagnosis of positive anti-HIV serology); and 2. Analysis of the educational booklet, with evaluative items (comprehension of texts and illustrations, motivation for reading and relevance). The answers to the questions were presented by dichotomous variables: (1) Yes - according to the item; (2) No - in disagreement with the item. There were spaces for suggestions.

\section{Analysis of results and statistics}

For data analysis, the proportion of evaluators who agreed on the positive evaluation of the items was measured ${ }^{(33)}$, adopting a percentage equal to or greater than $85 \%$ of agreement among the evaluators. Items with total percentage lower than $85 \%$ for any of the evaluated criteria were modified according to the suggestions of the evaluators or excluded ${ }^{(28)}$. To characterize the expert judges and PLWHAs, frequency distribution, central tendency measures, dispersion and normality tests were performed, considering the $95 \%$ confidence interval for quantitative variables.

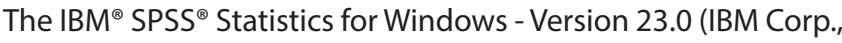
Armonk, NY, USA) software was used for statistical procedures.

\section{RESULTS}

\section{Development of the educational booklet}

The booklet had a cover entitled "My motivation for change! Practices for promoting a healthy lifestyle", followed by a back cover with technical data of authorship, page presenting the theme to the target audience, and another for summary. Then, the sub-themes of the booklet were presented: 1 . body weight control; 2 . healthy 
eating; 3. exercise practice; 4 . smoking, alcohol and other drugs; 5. stress control; 6 . drug treatment. For each sub-theme, sections were formulated on the contents. In order to make the material more accessible to the target audience, each sub-theme had: open questions for direct communication with the reader, in order for him/her to reflect on the subject; and conversations among the characters of the booklet, who had different age groups, sex and ethnicity.

In sub-theme 1, the section "In search of the ideal weight" was formulated, about attitudes that make it difficult to maintain the ideal weight, and information on the measurement of the abdominal circumference of men and women was provided, to avoid cardiovascular diseases. In sub-theme 2, the section "How would a healthy diet be?" was elaborated, quoting recommendations on healthy food and salt consumption. In subtheme 3, the section "Becoming physically active", the importance of physical exercise, examples and difference between moderate and vigorous physical activity were discussed. Subtheme 4 had two sections: "The importance of quitting smoking and not using alcohol and other drugs" and "Drug use increases risk behaviors". The first section exposed the consequences of using these substances, and the second showed the importance of professional help when necessary. In sub-theme 5, the section "How to relax and be lighter" was formulated, bringing strategies for stress control and relaxation techniques. Subtheme 6 had the section "Taking medication correctly", which highlighted the importance of regular use of drugs and strategies for reminders to take them. It is worth pointing out that all the guidelines were based on the current guidelines ${ }^{(18,31)}$. At the end, there were two pages for records (date of consultation, blood pressure, weight, body mass index, viral load, CD4+T lymphocyte count, medication) and two pages to write down goals about healthy eating and exercise.

The textbook was organized in slides in Microsoft Power Point 2010 software and forwarded to illustration production, layout and layout by graphic designer. The designer used Adobe
Illustrator CS3 to make illustrations and Adobe InDesign CS6 for layout. Simple language and illustrations were used to better understand the booklet by the target audience. The first version of the booklet was printed on front and back, with colored ink, A5 size paper, dimensions of $14.8 \times 21 \mathrm{~cm}$, with a total of 27 pages.

\section{Content and appearance analysis by expert judges}

Twenty-two expert judges with expertise in HIV participated. There were 15 nurses (68.2\%), six doctors (27.3\%) and one nutritionist (4.5\%). Among them, 21 were female (95.5\%), aged between 28 and 62 years (mean \pm standard deviation: $42.0 \pm 10.3$ ). About the professional area, there were nine teaching nurses from public and private universities (40.9\%), six welfare nurses (27.3\%), six infectologists (27.3\%) and one nutritionist (4.5\%). The mean time of performance in the area was 13 years (standard deviation: \pm 9.5 ) and graduation was 18 years (standard deviation: \pm 10.1 years). Most specialists had a PhD $(15 ; 68.2 \%), 19$ (86.4\%) had at least one completed research involving HIV after the highest titre, 19 (86.4\%) were part of a research group, and all had articles published on HIV (22; 100\%). Most of the expert judges $(16 ; 72.7 \%)$ had experience in instrument validation studies and analysis of educational materials.

As for the evaluation of the content and appearance of the booklet, expert judges were given an evaluation tool consisting of Aspect 1 - Objectives (4 items); Aspect 2 - Structure, presentation, clarity and understanding of texts and illustrations (11 items); Aspect 3 - Relevance (3 items). Most of the items had the percentage of agreement proposed, with eight items with $95.5 \%$ positive agreement, five items with $90.9 \%$, two items with $86.4 \%$ and one item with $100 \%$ positive agreement among experts, which was the 2.8 of the aspect Structure, presentation, clarity and understanding of texts and illustrations. However, items 2.3 and 2.4 of this same aspect had a percentage of agreement below the established, respectively $77.3 \%$ and $81.8 \%$ (Table 1 ).

Table 1 - Evaluation of the aspects and items of the booklet by the expert judges, Fortaleza, Ceará, Brazil, 2019 ( $N=22)$

\begin{tabular}{|c|c|c|c|}
\hline Aspects and items in the booklet & $\mathbf{n}$ & $\%$ & $\mathrm{Cl} 95 \%$ \\
\hline \multicolumn{4}{|l|}{1 Objectives } \\
\hline 1.1 Is the booklet suitable to be used in consultations and health education strategies for PLWHA? & 20 & 90.9 & $69.37-98.40$ \\
\hline $\begin{array}{l}\text { 1.2 Are they consistent with the needs of PLWHA in terms of health education for lifestyle changes and prevention of } \\
\text { other diseases? }\end{array}$ & 21 & 95.5 & 75.11-99.76 \\
\hline 1.3 Does it contribute to adequate care for PLWHA? & 20 & 90.9 & $69.37-98.40$ \\
\hline 1.4 Is it suitable as scientific material for infectology? & 19 & 86.4 & $64.03-96.41$ \\
\hline \multicolumn{4}{|l|}{2 Structure, presentation, clarity and understanding of texts and illustrations } \\
\hline 2.1 Are the items in the booklet presented in a clear and objective way? & 20 & 90.9 & $69.37-98.40$ \\
\hline 2.2 Are the items presented scientifically correct? & 21 & 95.5 & 75.11-99.76 \\
\hline 2.3 Is the booklet suitable for the socio-cultural level of the target audience? & 17 & 77.3 & $54.17-91.31$ \\
\hline 2.4 Is the logical sequence of the proposed content adequate? & 18 & 81.8 & $58.99-94.00$ \\
\hline 2.5 Are the items well-structured in concordance and spelling? & 20 & 90.9 & $69.37-98.40$ \\
\hline 2.6 Is the size of the title and topics appropriate? & 20 & 90.9 & $69.37-98.40$ \\
\hline 2.7 Are the illustrations expressive and sufficient? & 19 & 86.4 & $64.03-96.41$ \\
\hline 2.8 Is the number of pages adequate? & 22 & 100 & 81.50-100 \\
\hline 2.9 Is the structure adequate and does it draw the attention of who will use it? & 21 & 95.5 & 75.11-99.76 \\
\hline 2.10 Is the reading pleasant, being a convenient material? & 21 & 95.5 & 75.11-99.76 \\
\hline 2.11 Is it suitable for use in hospitals, Primary Health Care units, among other places? & 21 & 95.5 & $75.11-99.76$ \\
\hline \multicolumn{4}{|l|}{3 Relevance } \\
\hline 3.1 Do the items portray key aspects that should be observed? & 21 & 95.5 & 75.11-99.76 \\
\hline $\begin{array}{l}3.2 \text { Is the booklet suitable to enable PLWHA to acquire information about the prevention and control of other chronic } \\
\text { diseases? }\end{array}$ & 21 & 95.5 & 75.11-99.76 \\
\hline 3.3 Is the booklet suitable for use by any nurse or other health professional attending PLWHA? & 21 & 95.5 & 75.11-99.76 \\
\hline
\end{tabular}

Notas: IC - intervalo de confiança; PVHIVs - pessoas vivendo com vírus da imunodeficiência humana. 
In item 2.3, which obtained agreement of $77.3 \%$, it was evaluated if the booklet was adequate to the socio-cultural level of the target audience. In this question, five experts answered no, justifying that, in the booklet, there were some technical terms that could hinder the understanding of the target audience; and suggested changes, which were complied with. In item 2.4, which obtained agreement of $81.8 \%$, it was evaluated if the booklet presented a logical sequence of the proposed content, and four expert judges answered no. The justifications were that in subtheme 1 (body weight control), more explanations on the subject were missing, such as what the ideal weight would be, information on Body Mass Index (BMI) and risks of being inadequate. Thus, a section was included in this sub-theme, entitled "What is the ideal weight?", putting the experts' suggestions. Some items that presented percentage of agreement within the established in the study also received suggestions for improvement of the material, and these were accepted.

The average was calculated for each of the evaluation aspects of the booklet and its global average. For Aspects 1 and 2, positive concordances of $90.9 \%$ were obtained by the expert judges, and Aspect 3 obtained concordance of $95.5 \%$. The overall average of positive agreement among the experts was $92.4 \%$. There was high agreement among the expert judges for the aspects evaluated individually and for the whole booklet. Thus, it was considered adequate as to content and appearance (Table 2).

Table 2 - Average of the evaluation aspects of the booklet and global average, Fortaleza, Ceará, Brazil, 2019

\begin{tabular}{lc}
\hline Aspects & $\%$ \\
\hline 1 Objectives & 90.9 \\
2 Structure, presentation, clarity and understanding of texts & 90.9 \\
and illustrations & \\
3 Relevance & 95.5 \\
Overall average of the booklet & 92.4 \\
\hline
\end{tabular}

After all the specialists' suggestions were analyzed and accepted by the researcher, the booklet was modified, and this was passed on to the graphic designer, who formatted the second version.

\section{Semantic analysis by PLWHAIVs}

There were 22 PLWHAs, 19 male (86.4\%) and 3 female (13.6\%), with ages ranging from 22 to 71 years (mean \pm standard deviation: $41 \pm 11.9$ ), education with a median of 12 years of study (interquartile range: 3 ), all from the category of sexual exposure, with a median of 5 years (interquartile range: 14) as the time of diagnosis.

The PLWHA received the second version of the booklet and the evaluation tool composed by: Aspect 1 - Understanding texts and illustrations ( 6 items); Aspect 2 - Reading motivation (4 items); Aspect 3 - Relevance (3 items). From this, the percentage of agreement of the positive answers of the patients was evaluated, being verified that all the evaluated items had positive agreement above $85 \%$, referring to the minimum percentage established in this study. Eleven items obtained $100 \%$ of positive agreement by the participants. Two items had $90.9 \%$ agreement, among which two participants marked "no" for item 1.5, and two marked "no" for item 1.6, both from the aspect of comprehension of texts and illustrations. However, these participants did not make any suggestions or comments regarding this aspect. The evaluation of the booklet items by PLWHA is described in Table 3.

The average was calculated for each of the evaluation aspects and its global average by the target audience. For Aspect 1, a positive agreement of $96.9 \%$ was obtained, while Aspects 2 and 3 obtained $100 \%$ agreement. The global average of positive agreement between the PLWHAs was $98.9 \%$. Thus, the booklet was considered adequate to be used by the target public (Table 4).

Besides answering the objective questions of the booklet's evaluation tool, the 22 PLWHA made comments on it: "The information is clear and addresses an important theme; The illustrations were representative of the information in the booklet, with beautiful and easy to understand drawings; The theme is important and I would like to take the booklet home; The booklet is excellent to be used by people with HIV; The booklet is beautiful and has explanatory illustrations; I liked the colors of the booklet and the theme; The size of the booklet is ideal, we can keep in the bag; The information is easy to follow in our daily lives.

Table 3 - Evaluation of aspects and items of the booklet by people living with the human immunodeficiency virus - Fortaleza, Ceará, Brazil, 2019 ( $\mathrm{N}=22)$

\begin{tabular}{|c|c|c|c|}
\hline Aspects and items in the booklet & $\mathbf{n}$ & $\%$ & $\mathrm{Cl} 95 \%$ \\
\hline \multicolumn{4}{|l|}{1 Understanding texts and illustrations } \\
\hline 1.1 Can you understand everything the booklet presents? & 22 & 100 & $81.50-100$ \\
\hline 1.2 Are the illustrations expressive and sufficient, serving as a complement to the text? & 22 & 100 & $81.50-100$ \\
\hline 1.3 Is the number of pages adequate? & 22 & 100 & $81.50-100$ \\
\hline 1.4 Is reading pleasant and educational material convenient? & 22 & 100 & $81.50-100$ \\
\hline 1.5 Is the booklet suitable for any literate PLWHA to read and understand? & 20 & 90.9 & $69.37-98.40$ \\
\hline 1.6 Did the cover get your attention? & 20 & 90.9 & $69.37-98.40$ \\
\hline \multicolumn{4}{|l|}{2 Reading motivation } \\
\hline 2.1 Did you feel motivated to read the booklet to the end? & 22 & 100 & $81.50-100$ \\
\hline 2.2 Did the educational booklet suggest thinking or acting on lifestyle changes to prevent/control other chronic diseases? & 22 & 100 & $81.50-100$ \\
\hline 2.3 Does the booklet address issues necessary for patients to feel motivated to follow health recommendations? & 22 & 100 & $81.50-100$ \\
\hline 2.4 Is the booklet suitable to enable PLWHA to follow health guidelines and have safety on the topic? & 22 & 100 & $81.50-100$ \\
\hline \multicolumn{4}{|l|}{3 Relevance } \\
\hline 3.1 Do the items in the booklet portray key aspects that should be observed by PLWHA? & 22 & 100 & $81.50-100$ \\
\hline $\begin{array}{l}3.2 \text { Is the booklet suitable to enable people living with HIV to obtain information about the prevention and control of } \\
\text { other chronic diseases? }\end{array}$ & 22 & 100 & $81.50-100$ \\
\hline 3.3 Is the booklet suitable for use by any nurse or other health professional attending PLWHA? & 22 & 100 & $81.50-100$ \\
\hline
\end{tabular}


Table 4 - Average of the evaluation aspects of the booklet and its global average in the third stage performed by people living with the human immunodeficiency virus - Fortaleza, Ceará, Brazil, 2019

\begin{tabular}{lc}
\hline Aspects & $\%$ \\
\hline 1 Understanding texts and illustrations & 96.9 \\
2 Reading motivation & 100 \\
3 Relevance & 100 \\
Overall average of the booklet & 98.9 \\
\hline
\end{tabular}

Most patients stated that there was no need to modify the booklet, analyzing it as approved. Thus, the second version did not need modifications, containing its final 30 pages. It should be noted that a cataloguing sheet page, one for references and one for the section suggested by the experts, with information on the appropriate weight and BMI, were included. The final booklet was forwarded for revision in Portuguese and graphic printing. After that, the copyright registration was requested to the National Library for public certification of authorship and ownership of the intellectual work developed.

\section{DISCUSSION}

The increased prevalence of obesity, overweight, hypercholesterolemia and metabolic syndrome has been observed in adults with $\mathrm{HIV}^{(34-35)}$. In Nigeria, the prevalence of overweight and obesity increased significantly with the time of HIV infection, and CD4+ T lymphocyte count greater than 350 cells $/ \mathrm{mm}^{3}$ was associated with four times higher chances for $\mathrm{SAH}^{(34)}$. In addition to the factors linked to infection, inadequate nutrition can also lead to the development of cardiovascular diseases ${ }^{(9-10,35)}$.

In this way, it is necessary to inform the PLWHA about the factors that predispose them to other comorbidities and how to prevent or control them. The use of educational materials allows the construction of knowledge, serves as a guide in cases of doubts of the patient and his family, helping in the daily decision making ${ }^{(36)}$. Effectively designed materials for health promotion can change the reality of a population and should be constructed in the context of the target audience ${ }^{(20)}$. The educational booklet produced in this study is a technology capable of orienting about the healthy lifestyle for PLWHA, seeking to improve the quality of life and prevent other diseases in this population.

The bibliographic survey stage contributed in the theoretical part of the booklet, identifying subjects to be addressed and improving the ideas of presenting information on promoting healthy lifestyle for PLWHA: body weight control; healthy eating; exercise; smoking, alcohol and other drugs; stress control; and drug treatment. Among the few studies that have developed primers on HIV, which addressed the prevention of motherto-child transmission in HIV-positive pregnant women ${ }^{(37)}$ and prevention of HIV infection in the elderly(38), also pointed out the bibliographic review as a fundamental step to identify relevant information for the booklet ${ }^{(37-38)}$.

The use of the theoretical framework to develop the booklet was the basis for planning how the subjects could be addressed, contributing to motivational, objective information, with open questions in each section, in order to make the reader reflect on their behavior related to the subject. In addition, the study emphasized that TTM can be considered a promising instrument for understanding health-related behavioral change ${ }^{(39)}$. In line with this, research has shown that health professionals, mainly doctors and nurses, use TTM in health education activities for people with chronic conditions and also associate it with other approaches to behavior change, such as the motivational interview, with healthy eating and physical activity being the most discussed topics ${ }^{(40)}$. Thus, theories are tools that can help in health education and in the elaboration of educational materials.

In the content and appearance analysis stage, we observed the multi-disciplinarity of the judges who evaluated the booklet, involving nurses, doctors and nutritionists. The participation of professionals from different areas is necessary to improve health behaviors. Other studies of construction and evaluation of printed educational materials also had specialized judges from different areas to evaluate the technology elaborated ${ }^{(21-23)}$. The relevance of the nurse as a member of the health team, who is responsible for care at all levels of care, playing an important role in sensitizing PLWHA about their health condition, agreeing with them goals and plans for behavior changes, is also highlighted.

The agreement of the expert judges on the appropriateness of the booklet corresponded, for the most part, to a value above that established in the survey, which was equal to or greater than $85 \%$. In other surveys of construction and evaluation of printed educational materials, the value greater than $80 \%$ of positive agreement between judges was considered valid ${ }^{(21,41)}$. In this study, two items were considered inadequate by the judges, suggesting changes in technical terms and addition of information in one domain of the booklet, and the suggestions were accepted. Adjustments are common when evaluating technologies, and it is essential to adapt to the suggestions of the judges, so that the material becomes complete, with scientific rigor and is understood by the target audience ${ }^{(42)}$. This suggestion of adjustments to improve the material developed was also observed in other studies, with the substitution of technical terms and textual adaptation to a more accessible language, as well as the reformulation of illustrations to better understand the reader ${ }^{(22,25,37)}$.

The subjects discussed in the booklet were written in simple language to make the content clearer. However, satisfactory Functional Health Lettering (FHL) is important for readers to understand and put health information into practice. It is noted that low FHL is related to less knowledge about the disease, difficulty in understanding health guidelines and lack of questioning of professionals, and communication tools are needed according to the needs and skills of patients ${ }^{(43)}$. Written materials with simplified language, illustrations and proper formatting can elevate the $\mathrm{FHL}$, as they facilitate the use of information according to user interest and deficit ${ }^{(44)}$.

The semantic analysis stage involved the target audience of the booklet, considering itself to be PLWHAs from different schools and socioeconomic classes. In the study in which a primer for prevention of mother-to-child transmission of HIV in HIV-positive pregnant women was built, half of the participants had until elementary school complete ${ }^{(37)}$. These aspects reveal the reality of the Brazilian population, therefore the booklet appears as a simple, reliable and valid technology for different economic and schooling strata, as long as individuals are able to read the material 
and understand $\mathrm{it}^{(23)}$. It is necessary to evaluate the educational material with different representatives of the target audience, to identify what has not been understood or is missing ${ }^{(45)}$.

The evaluation of the second version of the booklet by PLWHA, after suggestions from the expert judges, showed agreement above the minimum percentage established, with positive evaluation of the material as to the understanding of the texts, illustrations and relevance. This result was similar to another study in which a booklet on sexual activity of people with spinal cord injuries was built and evaluated, and the target audience considered the language and illustrations appropriate ${ }^{(22)}$.

The illustrations were well evaluated by the PLWHA in the space destined to the suggestions, mentioning that they complemented the text, were expressive and sufficient. As for the language, illustration and layout of the booklet, specific recommendations were followed ${ }^{(20)}$ : use of objective messages to facilitate reading and understanding, avoiding acronyms, technical-scientific terms and actions in the negative sense; adequate font size, as well as use of images and symbols familiar to the target audience, with drawings from various groups, ages and ethnic groups, so that the reader can identify himself; besides illustrations with attractive colors, to emphasize the important ideas of the text.

\section{Study limitations}

As a limitation of the study, we had the sampling for convenience in the semantic analysis stage of the booklet by PLWHA, being able to restrict the generalization of the results, because these apply to the study sample, which has its educational and cultural characteristics. Moreover, there was no participation of physical educator in the evaluation of content and appearance by expert judges, since professionals with the minimum criteria for inclusion in the study were not found.

\section{Contributions to Nursing, Infectious Diseases and Public Health}

The educational booklet can contribute to practices of health promotion by Nursing and other areas of care for PLWHA, helping in educational activities and in a complementary way in followup consultations, aiming at promoting a healthy lifestyle. As a consequence, the prevention/reduction of other chronic health conditions may occur. It is hoped that the booklet will be widely disseminated so that PLWHA can use the technology elaborated.

\section{CONCLUSION}

The booklet entitled "My motivation for change! Practices to promote healthy lifestyle" was built and had evidence of validity, being considered adequate by expert judges and target audience, which was verified by the percentage of positive agreement higher than $85 \%$ among the evaluators. In the semantic analysis, the participation of PLWHA made it possible to evaluate that the technology was adequate in terms of understanding texts and illustrations, motivation for reading and was relevant to help change the lifestyle of patients. It is hoped that the educational primer can promote changes to healthier health behaviors, preventing the occurrence and worsening of CNCD in PLWHA. For clinical evaluation of the booklet, randomized clinical trials involving PLWHA are suggested.

\section{REFERENCES}

1. Tang H, Mao Y, Tang W, Han J, Xu J, Li J. "Late for testing, early for antiretroviral therapy, less likely to die": results from a large HIV cohort study in China, 2006-2014. BMC Infect Dis. 2018;18(1):272. doi: 10.1186/s12879-018-3158-X

2. Poorolajal J, Hooshmand E, Mahjub H, Esmailnasab N, Jenabi E. Survival rate of AIDS disease and mortality in HIV-infected patients: a metaanalysis. Public Health. 2016;139:3-12. doi: 10.1016/j.puhe.2016.05.004

3. Hatleberg Cl, Ryom L, d'Arminio Monforte A, Fontas E, Reiss P, Kirk O, et al. Association between exposure to antiretroviral drugs and the incidence of hypertension in HIV-positive persons: the data collection on adverse events of anti-HIV drugs (D:A:D) study. HIV Med. 2018;19(9):605-18. doi: 10.1111/hiv.12639

4. Reddy KP, Kong CY, Hyle EP, Baggett TP, Huang M, Parker RA, et al. Lung cancer mortality associated with smoking and smoking cessation among people living with HIV in the United States. JAMA Intern Med. 2017;177(11):1613-21. doi: 10.1001/jamainternmed.2017.4349

5. Van Der Valk M, Reiss P. Noncommunicable diseases in people living with HIV: time for integrated care. JID. 2017;216(12):1481-83. doi: 10.1093/infdis/jix525

6. Gallant J, Hsue R, Shreay, S, Meyer N. Comorbidities among US patients with prevalent HIV infection: a trend analysis. JID. 2017;216(12):1525-33. doi: 10.1093/infdis/jix518

7. Silva JM, Sacilotto LB, Souza LR, Mendes AL, Mantovani MS. Alta prevalência de dislipidemia, excesso de peso e sedentarismo em pessoas vivendo com HIV/Aids. IJN. 2018;11(S 01):S24-S327. doi: 10.1055/s-0038-1674380

8. Ryscavage P, Still W, Nyemba V, Stafford K. Prevalence of systemic hypertension among HIV-infected and HIV-uninfected young adults in Baltimore, Maryland. South Med J. 2019;112(7):387-91. doi: 10.14423/SMJ.0000000000001001

9. Cunha GH, Lima MAC, Galvão MTG, Fechine FV, Fontenele MSM, Siqueira LR. Prevalence of arterial hypertension and risk factors among people with acquired immunodeficiency syndrome. Rev. Latino-Am Enfermagem. 2018;26:e3066. doi: 10.1590/1518-8345.2684.3066

10. Cunha GH, Franco KB, Galvão MTG, Lima MAC, Fontenele MSM, Siqueira LR, et al. Diabetes mellitus in people living with HIV/AIDS: prevalence and associated risk factors. AIDS Care. 2020;32(5):600-7. doi: 10.1080/09540121.2019.1695727 
11. Fahme SA, Bloomfield GS, Peck, R. Hypertension in HIV-infected adults: novel pathophysiologic mechanisms. Hypertension. 2018;72(1):4455. doi: 10.1161/hypertensionaha.118.10893

12. Masuku SKS, Tsoka-Gwegweni J, Sartarius B. HIV and antiretroviral therapy-induced metabolic syndrome in people living with HIV and its implications for care: a critical review. J Diabetol. 2019;10(2):41-7. doi: 10.4103/jod.jod_21_18

13. Maggi P, Di Biagio AD, Rusconi S, Cicalini S, D'abbraccio M, D'ettorre G, et al. Cardiovascular risk and dyslipidemia among persons living with HIV: a review. BMC Infect Dis. 2017;17(1):551. doi: 10.1186/s12879-017-2626-z

14. Mesquita CE, Hottz ED, Amancio RT, Carneiro AB, Palhinha L, Coelho LE, et al. Persistent platelet activation and apoptosis in virologically suppressed HIV-infected individuals. Sci Rep. 2018;8(1):14999. doi: 10.1038/s41598-018-33403-0

15. Njelekela M, Mpembeni R, Muhihi A, Ulenga N, Aris E, Kakoko D. Lipodystrophy among hiv-infected patients attending care and treatment clinics in dar es Salaam. Aids Res Treat. 2017;id3896539. doi: 10.1155/2017/3896539

16. Kumar S, Rao PSS, Earla R, Kumar A. Drug-drug interactions between anti-retroviral therapies and drugs of abuse in HIV systems. Expert Opin Drug Metab Toxicol. 2015;11(3):343-55. doi: 10.1517/17425255.2015.996546

17. Kader R, Govender R, Seedat S, Koch JR, Parry C. Understanding the impact of hazardous and harmful use of alcohol and/or other drugs on arv adherence and disease progression. PLoS One. 2015;10(5): e0125088. doi: 10.1371/journal.pone.0125088

18. Ministério da Saúde (BR). Secretaria de Vigilância em Saúde. Departamento de Vigilância. Prevenção e Controle das Infecções Sexualmente Transmissíveis, do HIV/Aids e das Hepatites Virais. Protocolo clínico e diretrizes terapêuticas para manejo da infecção pelo HIV em adultos [Internet]. Brasília; 2018 [cited 2019 Dec 20]. Available from: http://www.aids.gov.br/pt-br/pub/2013/ protocolo-clinico-e-diretrizes-terapeuticas-para-manejo-da-infeccao-pelo-hiv-em-adultos

19. Mosha NR, Mahande M, Juma A, Mboya I, Peck R, Urassa M, et al. Prevalence, awareness and factors associated with hypertension in North West Tanzania. Glob Health Action. 2017;10(1): 1321279. doi: 10.1080/16549716.2017.1321279

20. Moreira MF, Nóbrega MML, Silva MIT. Written communication: contribution for the elaboration of educational material in health. Rev Bras Enferm. 2003;56(2):184-8. doi: 10.1590/S0034-71672003000200015

21. Abreu ACS, Marinho DF, Cardoso IBP. Educational technology for caregivers of patients with tracheostomy: validation study. Rev Aten Saúde. 2019;17(59):19-32. doi: 10.13037/ras.vol17n59.5730

22. Silva RA, Ximenes LB, Cruz AG, Oliveira MAA, Araújo MFM, Andrade LM, et al. Sexual activity of people with spinal cord injury: development and validation of an educational booklet. Acta Paul Enferm. 2018;31(3):255-64. doi: 10.1590/1982-0194201800037

23. Sabino LM, Ferreira AMV, Joventino ES, Lima FET, Penha JC, Lima KF. Elaboration and validation of a reader on childhood diarrhea prevention. Acta Paul Enferm. 2018;31(3):233-9. doi: 10.1590/1982-0194201800034

24. Mourão GP, Sanches ACO, Medeiros AG, Pedrosa AVA, Pascoa MGS, Câmara TMS, et al. Construction and validation of educational booklet for preventing falls in older people: home care guidelines. Rev Expressão Católica Saúde. 2018;3(1):20-7. doi: 10.25191/recs.v3i1.2142

25. Rosa R, Costa R, Souza AIJ, Lima MM, Schneider DG, Santos EKA. Reflections of nurses in search of a theoretical framework for maternity care. Rev Bras Enferm. 2018;71(suppl3):1432-8. doi: 10.1590/0034-7167-2016-0525

26. Prochaska JO, Norcross JC, Diclemente CC. Applying the stages of change. Psychother Australia [Internet]. 2013 [cited 2020 Aug 30];19(2):10-15. Available from: https://www.researchgate.net/publication/285796052_Applying_the_Stages_of_Change

27. Conselho Nacional de Saúde (BR). Resolução № 466, de 12 de dezembro de 2012. Diretrizes e Normas Regulamentadoras de Pesquisas Envolvendo Seres Humanos.

28. Lopes MVO, Silva VM, Araujo TL. Methods for establishing the accuracy of clinical indicators in predicting Nursing Diagnoses. Int J Nurs Knowl. 2012;23(3):134-9. doi: 10.1111/j.2047-3095.2012.01213.x

29. Lira ALBC, Lopes MVO. Nursing diagnosis: educational strategy based on problem-based learning. Rev Latino-Am Enfermagem. 2011;19(4):936-43. doi: 10.1590/S0104-11692011000400012

30. Suka M, Odajima T, Kasai M, Igarashi A, Ishikawa H, Kusama M, et al. The 14-item health literacy scale for Japanese adults (HLS-14). Environ Health Prev Med. 2013;18(5):407-15. doi: 10.1007/s12199-013-0340-z

31. Ministério da Saúde (BR). Secretaria de Atenção à Saúde. Departamento de Atenção Básica. Diretrizes para o cuidado das pessoas com doenças crônicas nas redes de atenção à saúde e nas linhas de cuidado prioritárias [Internet]. Brasília; 2013 [cited 2019 Dec 20]. Available from: http://bvsms.saude.gov.br/bvs/publicacoes/diretrizes\%20_cuidado_pessoas\%20_doencas_cronicas.pdf

32. Doak CC, Doak LG, Root JH. Teaching patients with low literacy skills. 2nd ed. Philadelphia: JB Lippincott Company; 1996.

33. Polit DF, Beck CT. Fundamentos de Pesquisa em enfermagem: avaliação de evidências para as práticas da enfermagem. 7th ed. Porto Alegre: Artmed; 2011

34. Aridegbe M, Adeoye I, Oguntade A. Obesity, hypertension, and dyslipidemia among human immunodeficiency virus patients in Abeokuta Ogun State, Nigeria. Nig J Cardiol. 2019;16(1):83-91. doi: 10.4103/njc.njc_10_18

35. Deresz LF, Brito C, Schneider CD, Rabito El, Ikeda MLR, Lago PD. Dietary intake and cardiovascular risk among people living with HIV/aids. Ciênc Saúde Colet. 2018;23(8):2533-42. doi: 10.1590/1413-81232018238.20542016

36. Siddharthan T, Rabin T, Canavan ME, Nassali F, Kirchhoff P, Kalyesubula R, et al. Implementation of patient-centered education for chronicdisease management in Uganda: an effectiveness study. PLoS One. 2016;11(11):e0166411. doi: 10.1371/journal.pone.0166411 
37. Lima ACMAC, Bezerra KC, Sousa DMN, Rocha JF, Oriá MOB. Development and validation of a booklet for prevention of vertical HIV transmission. Acta Paul Enferm. 2017;30(2):181-9. doi: 10.1590/1982-0194201700028

38. Cordeiro LI, Lopes TO, Lira LEA, Feitoza SMS, Bessa MEP, Pereira MLD, et al. Validation of educational booklet for HIV/aids prevention in older adults. Rev Bras Enferm. 2017;70(4):775-82. doi: 10.1590/0034-7167-2017-0145

39. Toral N, Slater B. Transtheoretical model approach in eating behavior. Ciênc Saúde Coletiva. 2007;12(6):1641-50. doi: 10.1590/ S1413-81232007000600025

40. Lima GCBB, Guimarães AMDN, Silva JRS, Otero LM, Gois CFL. Health education and methodological devices applied in the care of Diabetes Mellitus. Saúde Debate. 2019;43(120):150-8. doi: 10.1590/0103-1104201912011

41. Nascimento MHM, Teixeira E. Educational technology to mediate care of the "kangaroo family" in the neonatal unit. Rev Bras Enferm. 2018;71(S 3):1290-7. doi: 10.1590/0034-7167-2017-0156

42. Castro EK, Teixeira V, Duarte MQ. Evaluation of educational material about the prevention of breast cancer. Mudanças Psicol Saúde. 2017;25(2):51-7. doi: 10.15603/2176-1019/mud.v25n2p51-57

43. Chehuen JA, Costa LA, Estevanin GM, Bignoto BC, Vieira CIR, Pinto FAR, et al. Functional Health Literacy in chronic cardiovascular patients. Ciênc Saúde Colet. 2019;24(3):1121-32. doi: 10.1590/1413-81232018243.02212017

44. Cunha GH, Galvão MTG, Pinheiro PNC, Vieira NFC. Health literacy for people living with HIV/aids: an integrative review. Rev Bras Enferm. 2017;70(1):169-77. doi: 10.1590/0034-7167-2015-0052

45. Echer IC. The development of handbooks of health care guidelines. Rev Latino-Am Enfermagem. 2005;13(5):754-7. doi: 10.1590/ S0104-11692005000500022 